\title{
Revisiting the Factors behind European External Imbalances
}

\author{
Carlos A. Carrasco \\ Universidad de Monterrey (UDEM), San Pedro Garza Garcia, Mexico \\ Adrian Hernandez-del-Valle \\ Instituto Politécnico Nacional (SEPI-ESE-IPN), Mexico City, Mexico
}

\begin{abstract}
In this paper, we develop four hypotheses for the origins of European imbalances in the context of the European economic integration process. To test the validity of our hypotheses for Germany and Spain, we implement an Autoregressive Distributed Lag bounds testing approach. According to our results, in the German case, economic and financial integration and non-price competitiveness have played a key role in the evolution of the external balance, whilst for Spain, the external balance is related to catching-up. In addition, there is no evidence of a long-run relationship between public finance and external imbalances. We derive important policy implications. On the one hand, deficit countries should ensure that the capital inflows from abroad are allocated to industries with high-added value. On the other hand, surplus countries require the implementation of an expansive economic policy, to lessen the burden of deficit countries when trying to address external imbalances.
\end{abstract}

\section{JEL Classifications: F15, F32, F36}

Keywords: European External Imbalances, Current Account, Economic Integration, Catching-up, Competitiveness

\footnotetext{
* Corresponding author: Carlos A. Carrasco; Departamento de Economía, Universidad de Monterrey (UDEM), Av. Ignacio Morones Prieto 4500 Pte., 66238, San Pedro Garza García, Nuevo León, México. Tel.: (00521) 2481604574, Email: carlos.carrasco@udem.edu

Co-author: Adrian Hernandez-del-Valle; Escuela Superior de Economía, Instituto Politécnico Nacional (SEPI-ESE-IPN), Plan de Agua Prieta 66, Col. Del. Miguel Hidalgo, 11340, Ciudad de México, México. Tel.: (0052) 5557296000, ext. 62036, Email: ahdv@hotmail.com 


\section{Introduction}

As has been widely documented, the Eurozone has had a net current account close to balance, whereas at country level, member states have had significant and persistent diverging trends in their external balances. From a historical perspective, these imbalances existed before the introduction of the euro; however, since the introduction of the single currency, these diverging trends have increased, as in Carrasco (2015). Nevertheless, before the beginning of the global financial crisis in 2007, such intraEuropean imbalances were understood as being a natural consequence of the expected catching-up process, and therefore they were not perceived as a source of instability, but rather as part of the economic integration process, per Blanchard and Giavazzi (2002), with peripheral countries (e.g., Greece) presenting a credible commitment to belonging to the Eurozone, and core countries interested in monitoring the convergence of Eurozone countries, as Arghyrou and Tsoukalas (2011) suggested. However, since the start of the global financial crisis and the European sovereign debt crisis, academic research has paid increasing attention to these imbalances due to their possible link with the origin of the crisis. This research included works by Alessandrini et al. (2014), Arghyrou and Chortareas (2008), Barnes, Lawson, and Radziwill (2010), Belke and Dreger (2013), Blanchard (2007), Brissimis et al. (2012), Campa and Gavilán (2011), Chen, Milesi-Ferretti, and Tressel (2013), Gehringer (2015), Gibson, Hall, and Tavlas (2012), and Schmitz and von Hagen (2011). Accordingly, those Eurozone countries presenting persistent and significant negative external positions before the crisis (e.g., Greece, Portugal, and Spain) faced a steep fall in their growth rates once the crisis began.

In this study, we analyse the key hypotheses highlighted in the economic literature regarding the origin of European external imbalances. We develop a theoretical and empirical framework to show evidence of each hypothesis for Germany and Spain. We summarise these hypotheses in terms of: 1) catching-up in the context of economic and financial integration, 2) disparities in price and non-price competitiveness, 3) the role of public finance, and 4) the aging process and its effects through savings rates. To validate our hypotheses empirically, we implement Auto Regressive Distributed Lag (ARDL) bounds tests, as proposed by Pesaran and Shin (1999) and Pesaran, Shin, and Smith (2001).

The motivation of this paper is twofold. On the one hand, we aim to develop each hypothesis related to the origin of European external imbalances on theoretical grounds. 
On the other hand, we try to validate each hypothesis empirically. To our knowledge, no other paper has developed all these hypotheses individually yet.

The paper is structured as follows. In the second section, we analyse and develop each hypothesis related to the origin of Eurozone external imbalances on a theoretical basis. In the third section, we describe the methodology and data sources. In the fourth section, we show our econometric results for the cases of Germany and Spain. Finally, we make some concluding remarks. According to our results, the German external balance is connected to economic and financial integration and non-price competitiveness, whereas for Spain, the external balance is related to the catching-up process. In addition, for neither country is there any evidence indicating that public finance has played a key role in the origin of external imbalances.

\section{The Origins of European Imbalances}

Since the beginning of the global financial crisis, and particularly after the outbreak of the European sovereign debt crisis, there has been an emergence of economic literature analysing the determinants of external European imbalances. This included Arghyrou and Chortareas (2008), Belke and Dreger (2013), Campa and Gavilán (2011), Carrasco and Peinado (2015), Chen, Milesi-Ferretti, and Tressel (2013), Gehringer (2015), and Schmitz and von Hagen (2011). We depart from previous economic literature to develop a theoretical framework of the factors behind European imbalances. To our knowledge, no other paper has analysed individually the four hypotheses with respect to the emergence of such imbalances. In the remainder of the paper, we fill this gap formally and empirically.

\section{A. Hypothesis 1: catching-up and economic integration}

Hypothesis 1 is associated with the expected catching-up process due to European economic and financial integration, whereby countries in a relatively low stage of development converge towards those countries with a higher level of development, per Belke and Dreger (2013), Blanchard and Giavazzi (2002), Campa and Gavilan 
(2011), Gehringer (2015), and Schmitz and von Hagen (2011). In relation to this, capital should flow from core countries towards southern European countries, and these capital flows will push peripheral countries into a negative net current account. From this viewpoint, European external imbalances have not been considered a source of instability, but a natural part of the economic and financial integration process, with subsequent imbalances correction once real convergence is attained. In addition, capital flows towards southern European countries were incentivised when the exchange rate risk disappeared after the adoption of the single currency. However, there is evidence indicating that at least some expectations of higher returns were not aligned with macroeconomic fundamentals, as in Beirne and Fratzscher (2013), and Gibson, Hall and Tavlas (2012), as well as Ca'Zorzi et al. (2012) for an example of non-Eurozone major economies, and Arghyrou and Kontonikas (2012) for non-market pricing behaviour. In summary, the process of economic and financial integration of the European Economic and Monetary Union (EMU) should attract capital flows from core countries of the Eurozone towards catching-up countries looking for higher marginal returns.

Equations (1) to (3) summarise Hypothesis 1. According to this hypothesis, in country $i$ at time $t$, the domestic interest rate, IntRates ${ }_{t, i}$, is equal to an external interest rate, IntRates ${ }_{t, i}^{e}$, plus a country factor reflecting the risk premium, Risk ${ }_{t, i}$. Due to economic and financial integration, the country risk premium (technically) disappears $\left(\operatorname{Risk}_{t, i} \rightarrow 0\right)$, and domestic interest equaled the external interest rate:

$$
\text { IntRates }_{t, i}=\text { IntRates }_{t, i}^{e}+\text { Risk }_{t, i} \approx \text { IntRates }_{t, i}^{e}
$$

Moreover, investment, $I_{t, i}$, responds to higher economic growth, $G D P_{t, i}$, due to the catching-up process, and to lower domestic interest rates, IntRates ${ }_{t, i}$, once the risk premium decreases. This economic growth depends on the developmental stage reflected in Gross Domestic Product (GDP) per capita, GDPpc : $_{t, i}$

$$
G D P_{t, i}=f\left(G D P p c_{t, i}\right)
$$

In addition, investment is incentivised by capital inflows as a response to financial liberalisation, FinOp $p_{t, i}$. To summarise, the external balance, $E B_{t, i}$, of country $i$ per Hypothesis 1 is given by: 


$$
\begin{aligned}
& E B_{t, i}=f\left(G D P p c_{t, i}, \text { IntRates }_{t, i}, \text { FinOp }_{t, i}\right) \\
& -\quad-\quad+/
\end{aligned}
$$

Following a classical approach to economic growth, a less developed country tends to grow faster than a more developed country, increasing its demand for imports and thus worsening the external balance (negative sign). In addition, those countries with lower levels of development within the EMU have benefited from financial liberalisation with a decrease in interest rates, encouraging borrowing abroad and worsening the external balance. Finally, the sign of the variable accounting for liberalisation of the financial market depends on the development level of the country: in a relatively less developed country, a worsening of the current account is expected due to capital flows going into that country (negative sign), whereas in the case of a more developed country, financial openness represents an opportunity for investment abroad (positive sign for highly developed countries).

\section{B. Hypothesis 2: price and non-price competitiveness}

Hypothesis 2 focuses on the loss of relative competitiveness of those countries that need to converge with respect to the core countries, per Arghyrou and Chortareas (2008), Belke and Dreger (2013), and Blanchard (2007). According to this hypothesis, the evolution of the current account depends on price and non-price competitiveness, and on those factors related to the current economic policy design of the EMU that affect competitiveness. By price competitiveness, we refer to trends in prices and wages relative to partner countries (for example, real exchange rates); by non-price competitiveness, we refer to the compositions of exports, economic specialisation, and quality of products.

Regarding price competitiveness, the structures which make up collective bargaining, and which directly influence the evolution of prices and wages, would have a direct effect on the price component of competitiveness by setting wage growth rates higher than productivity growth rates. However, the price component of competitiveness does not explain trade performance in its entirety. Christodoulopoulou and Tkacevs (2016) show evidence of non-price-related factors playing a key role in trade performance.

With respect to non-price competitiveness, countries with an economic structure that enables them to adapt to an integrated world economy tend to present a structural external surplus; in other words, the composition of exports matters for external 
imbalances, as presented in Wierts, van Kerkhoff, and de Haan (2014). These surplus countries are characterised by having large industries incorporating high-skilled labour, and producing goods and services with high added-value in terms of quality, variety, and exclusiveness. In these surplus countries, the weight of the tradable sector is relatively greater than in the case of deficit countries, and it can present significant productivity increases, i.e., such tradable sectors are over, or close to, the technological frontier, and their competitiveness is not based on low prices and wages.

Finally, the structural design of the Eurozone could allow macroeconomic imbalances to be maintained as per De Grauwe (2014). The absence of a budgetary union helps to create different business cycles at the national level. For example, an expansive fiscal policy in one of the Eurozone member countries could temporarily boost the economy and increase the degree of de-synchronisation of business cycles with respect to other member countries. In this case, with different business cycle stages, a common monetary policy will be ineffective. If some countries are in expansion, while others are in contraction, both groups of countries will need to adopt a different kind of policy stance. In the case that the central bank decides to follow an expansive monetary policy, some countries will obtain the necessary stimulus to return to their potential level of GDP growth. However, other countries will overheat, with inflationary pressures and a loss of relative price competitiveness.

In addition, the Stability and Growth Pact (SGP) limits the capacity of national governments to respond when facing a negative shock in at least two ways. First, the responses of national governments to negative shocks are restricted to a limit of a maximum 3 per cent of fiscal deficit, and an upper limit of 60 per cent in the debt-toGDP ratio. Second, financial markets could jeopardise the fiscal stability of national governments by imposing a higher risk premium when fiscal authorities increase their deficit to respond to negative shocks. Finally, there is little use of a wage and income policy as a coordination mechanism to correct the diverging trend in the relationship between productivity and wages, as in Ferreiro and Gómez (2014).

We summarise Hypothesis 2 in Equations (4) to (7). In this case, the external balance in country $i$ at time $t, E B_{t, i}$, is a function of price competitiveness, $Z_{t, i}^{P}$, and non-price competitiveness, $Z_{t, i}^{N}$, where increases in $Z_{t, i}^{P}$ and $Z_{t, i}^{N}$ represent gains in price and nonprice competitiveness, respectively.

$$
E B_{t, i}=f\left(Z_{t, i}^{P}, Z_{t, i}^{N}\right)
$$


On the one hand, price competitiveness, $Z_{t, i}^{P}$, is a function of the degree to which unions, UNIONS ${ }_{t, i}$, in that country can influence wage-setting - which depends on the structure and institutions of the domestic labour market - and of the evolution of unit labour costs, $R U L C_{t, i}$. When the economy presents a rate of unemployment lower than the long-term rate, unions could have greater influence on wage-setting, such as setting a rate of growth of wages higher than the rate of productivity growth. In this case, country $i$ would present a loss of price competitiveness. In contrast, when an economy presents a high rate of unemployment, the bargaining power of unions is weaker.

$$
Z_{t, i}^{P}=f\left(U N I O N S_{t, i}, R U L C_{t, i}\right)
$$

On the other hand, non-price competitiveness, $Z_{t, i}^{N}$, is a function of the quality, variety, and exclusiveness of goods and services produced in a country. For simplicity, we assume that non-price competitiveness is proxied by research and development expenditure, $R a n d D_{t, i}$. These factors are related to the country specialisation and its capacity to produce goods and services with higher added-value.

$$
Z_{t, i}^{N}=f\left(\operatorname{Rand}_{t, i}\right)
$$

In both cases, the external balance also depends on the degree of trade openness, $T R A D E_{t, i}$, as a price competitive and/or a non-price competitive country will benefit from increasing trade with the rest of the world (positive sign). In brief, per Hypothesis 2 , the external balance is given by:

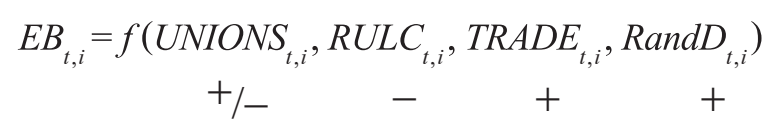

In this case, the effect of unions will depend on their bargaining power and their role as wage moderators. Moreover, for those countries where real unit labour costs grow faster (losing price competitiveness), a worsening of the external balance could be expected. Finally, the higher the specialisation in high-added value industries (a measure of non-price competitiveness), the larger the expected surplus (positive sign). 


\section{Hypothesis 3: the role of public finance}

Hypothesis 3 links the external position of EMU countries to the fiscal position of governments' budget balance in terms of so-called twin deficits. For the case of the Eurozone, the evidence is not generalised, i.e., for some countries there is a relationship between the fiscal policy stance and the current account, whereas for other countries this is not the case, as in Barnes, Lawson, and Radziwill (2010), Brissimis et al. (2012), and Blanchard (2007). In relation to this, most of the problems related to external imbalances have their origins in savings/investment decisions on the part of the private sector (Hein, Truger, and van Treeck 2012). However, at the beginning of the global financial crisis, Eurozone governments increased public expenditure to mitigate the effects of private sector deleveraging in the economy. Nevertheless, the differences in fiscal positions were significant at the beginning of the crisis. For example, Greece and Italy presented a ratio of debt to GDP higher than the upper limit imposed by the SGP, whereas Spain's debtto-GDP ratio was among the lowest in the Eurozone.

In Equations (8) to (13) we develop Hypothesis 3. We assume:

$$
\left(S_{t, i}-I_{t, i}\right)-E B_{t, i}=\left(G_{t, i}-T_{t, i}\right)
$$

where $S_{t, i}$ are private savings in country $i$ at time $t, I_{t, i}$ is private investment, $T_{t, i}$ are tax revenues, and $G_{t, i}$ represents government expenditures. Simplifying such that $S_{t, i}=$ $I_{t, i}$, gives:

$$
-E B_{t, i}=\left(G_{t, i}-T_{t, i}\right)
$$

As the European Central Bank (ECB) is not allowed (directly) to fund national public deficits, total government revenues, $R_{t, i}^{T}$, come from taxes, $T_{t, i}$, and the issuing of new

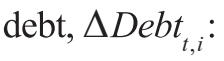

$$
R_{t, i}^{T}=T_{t, i}+\Delta D e b t_{t, i}
$$

Following Carlin and Soskice (2006), the issuing of new debt, $\Delta D_{e b t} t_{t, i}$, will be given by the primary deficit, $G_{t, i}-T_{t, i}$, and the dynamics of the debt, i.e., the difference between the interest rate, IntRates ${ }_{t, i}$, and the rate of growth of the economy, GDP ${ }_{t, i}$, multiplied by the actual ratio of debt to GDP, Debt $t_{t, i}$. 


$$
\Delta \operatorname{Debt}_{t, i}=\left(G_{t, i}-T_{t, i}\right)+\left[\left(\text { IntRates }_{t, i}-G D P_{t, i}\right) \operatorname{Debt}_{t, i}\right]
$$

Rewriting Equation (9) and Equation (11), we have:

$$
E B_{t, i}=\left[\left(\text { IntRates }_{t, i}-G D P_{t, i}\right) \text { Debt } t, i\right]-\Delta D e b t_{t, i}
$$

In this case, new issuing of public debt will worsen external balances (negative sign). In addition, IntRates ${ }_{t, i}$ and $G D P_{t, i}$ affect the debt dynamics and long-term debt sustainability. On the one hand, a high rate of economic growth will reduce the debt burden in two ways (positive sign is expected): first, the country will be able to pay an amount of the debt service to decrease the debt level; second, due to the high economic growth and the credibility associated with paying debt services, economic agents will reduce the risk premium, which improves the probability of this country servicing its debt. On the other hand, the higher the interest rate, the greater the difficulties in addressing debt service, i.e., a high rate of interest will increase the level of the debt, thus resulting in a deterioration of the external balance (negative sign). Overall, we have:

$$
E B_{t, i}=f\left(\text { Debt }_{t, i}, \text { IntRates }_{t, i}, G D P_{t, i}\right)
$$

\section{Hypothesis 4: aging population and savings}

Finally, Hypothesis 4 is based on differences in population structure and old-agedependency ratio projections, and the effects on savings rates as in Aizenman and Sengupta (2011), Barnes, Lawson, and Radziwill (2010), and Hassan, Salim, and Bloch (2011). Countries with a higher expected old-age-dependency ratio show higher savings rates in comparison to those countries with younger populations. Accordingly, this excess of savings will be channelled to countries with higher marginal returns, and it will be manifested in the different external positions of EMU countries.

In a two-period framework, given the preference for smooth consumption in an economy with an aging population, savings, $S_{t, i}$, will be higher, as they will compensate for the relative fall in income induced by the aging process to achieve a consumption level that is similar in both periods.

In addition, if social security protection is weak and the economy is expecting an 
increase in health care consumption in the next period, $S_{t, i}$ will be even higher to address aging-related consumption, so that if $G D P_{t, i}>E_{t, i} G D P_{t+1, i}, S_{t, i}=Y_{t, i}^{D}-C_{t, i}$ will be set such that $C_{t, i} \mid G D P_{t, i}, E_{t, i} G D P_{t+1, i}$, equivalent to $C_{t+1, i} \mid S_{t, i}, G D P_{t+1, i}$. In summary, ceteris paribus, the closer the expected aging process, the higher the savings rate and the higher net exports, and vice versa.

We summarise Hypothesis 4 in Equations (14) to (17). For simplicity, we assume that $T_{t, i}-G_{t, i}=0:^{1}$

$$
\left(S_{t, i}-I_{t, i}\right)=E B_{t, i}
$$

Due to the expected aging process, in a country with an older society, $S_{t, i}$ will be higher than $I_{t, i}$ and therefore $E B_{t, i}>0$. In this case, DepRat reflects the effects of aging on savings (the higher DepRat ${ }_{t, i}$, the higher $S_{t, i}$ ):

$$
S_{t, i}=f\left(\text { DepRat }_{t, i}\right)
$$

Further, investment, $I_{t, i}$, is a function of economic growth, $G D P_{t, i}$, and the interest rate, IntRates $_{t, i}$.

$$
I_{t, i}=f\left(G D P_{t, i}, \text { IntRates }_{t, i}\right)
$$

Overall, a country with an expected old society will present an external surplus, because of the effects of aging on savings plus lower expected growth in the next period.

$$
\begin{aligned}
& E B_{t, i}=f\left(\text { DepRat }_{t, i}, G D T_{t, i}, \text { IntRates }_{t, i}\right) \\
& +/-\quad-/+\quad+/-
\end{aligned}
$$

Contrarily, a country with a younger society should expect an external deficit, not only through the effect of the aging factor, but also due to higher growth.

In summary, the signs will depend on the stage of the aging process: as a society grows older, its savings will increase, and therefore the external balance will be positive to address future expenditure associated with old societies (positive sign). However, an

\footnotetext{
'We simplify by assuming $T_{t, i}-G_{t, i}=0$. However, the expected aging process will have effects on the public finance. For example, when a society is close to aging, public savings in time $t$ will increase $\left(T_{t, i}-G_{t, i}>0\right)$. This will be most evident in those countries with better social security protection and public pension schemes.
} 
elderly society will exhibit dissaving (negative sign).

\section{Data and Methodology}

As previously mentioned, for the empirical analysis we study Germany and Spain. Although several countries have persistently presented external surpluses (Germany, Austria, the Netherlands) and deficits (Spain, Greece, Portugal), Germany and Spain are selected for three main reasons. First, both countries are founding members of the Eurozone, which allows us to have a comparable time horizon. Second, both countries have the largest external imbalances in absolute terms among the Eurozone member states (Figure 1). Finally, among the group of Eurozone countries with relatively larger imbalances, Germany and Spain are, respectively, the first and fourth economies in absolute terms, which highlights their importance within the set of countries that have adopted the euro, and the potential risks to the euro area and the global economy that these imbalances could imply. Although Italy has experienced large and persistent external deficits, and the size of its economy is larger than the Spanish economy, in absolute terms Spain's external imbalances are larger. In addition, the adjustment resulting from the European sovereign debt crisis in Spain has been reflected in higher unemployment rates than those observed in Italy.

We focus on Germany and Spain for the period 1980 2012. In Table 1 we present a description of the set of variables, their abbreviations, their units of measurement, and the date of consultation. We use the series balance on current transactions with the rest of the world as share of GDP (hereinafter EB) as an approximation for external balances. 
Figure 1. Balance on the current transactions with the rest of the world

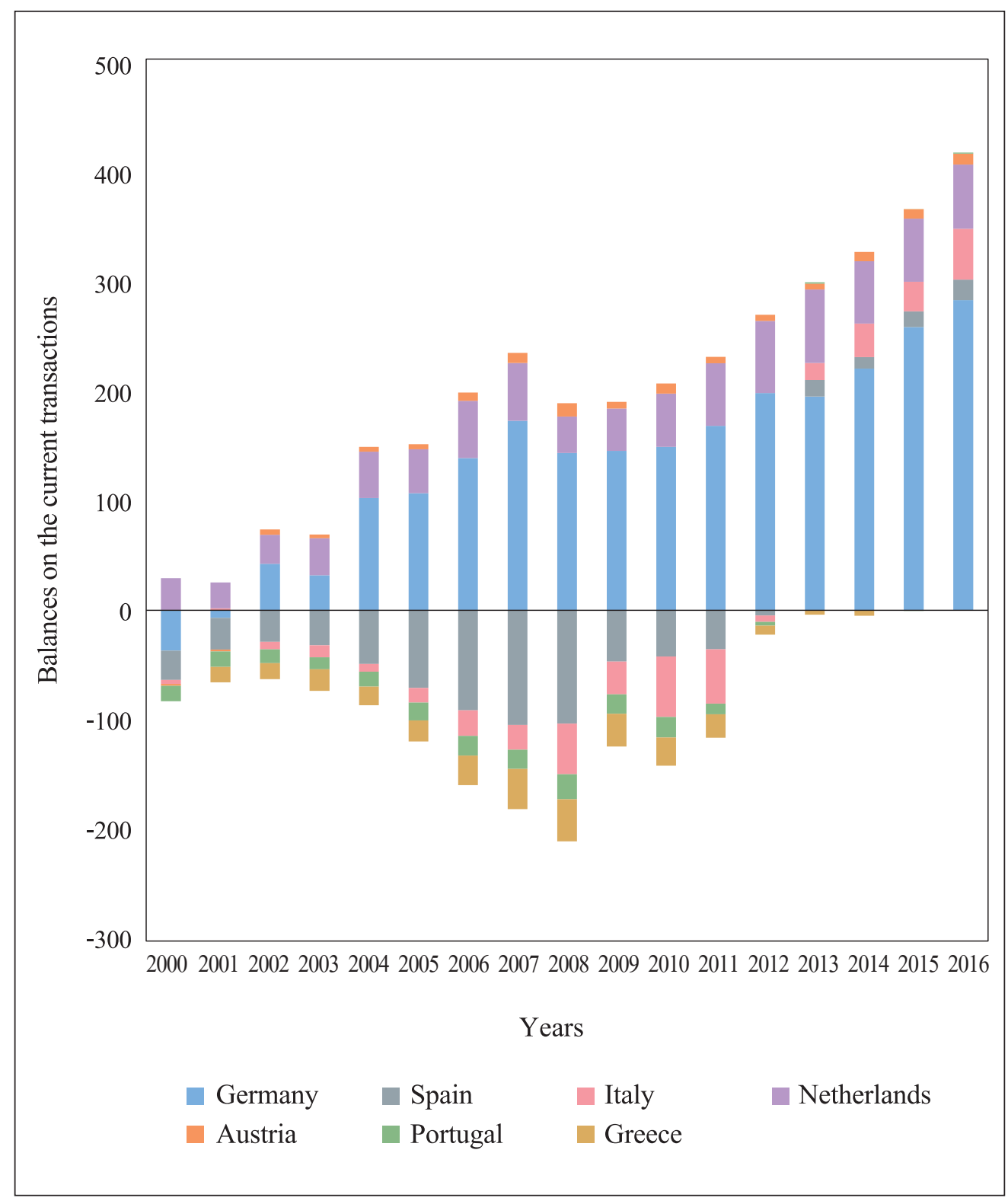

(Note) Selected Eurozone countries, in billion euros.

(Source) AMECO database. 


\begin{tabular}{|c|c|c|c|c|c|c|c|c|}
\hline$\frac{0}{2}$ & 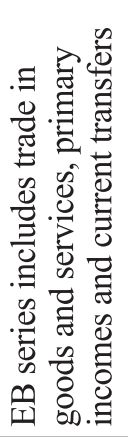 & 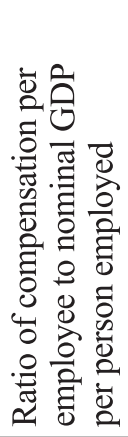 & 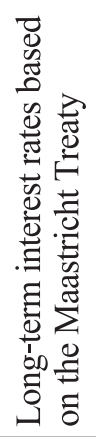 & 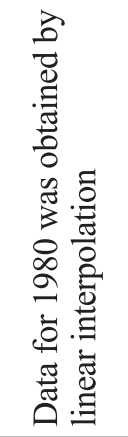 & & 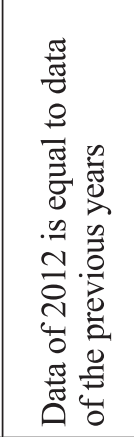 & & 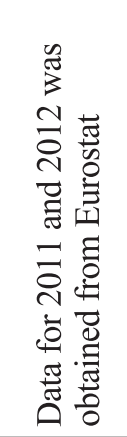 \\
\hline 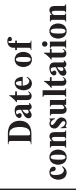 & 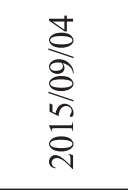 & 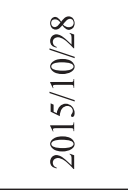 & 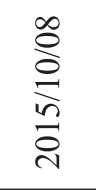 & 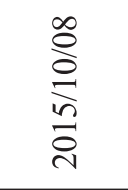 & $\frac{\stackrel{\infty}{\rho}}{\stackrel{0}{\frac{n}{n}}}$ & 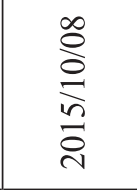 & $\frac{\Delta}{\frac{\Delta}{2}}$ & $\frac{\infty}{0}$ \\
\hline 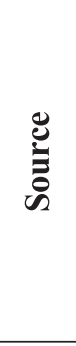 & 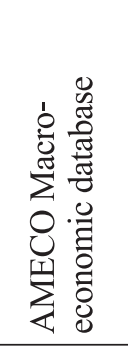 & 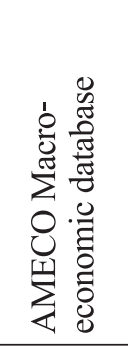 & 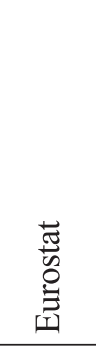 & 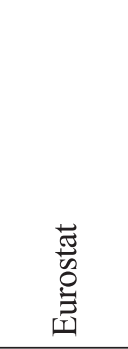 & 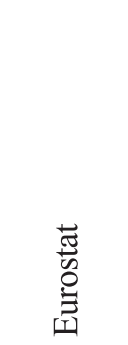 & 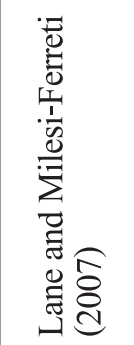 & 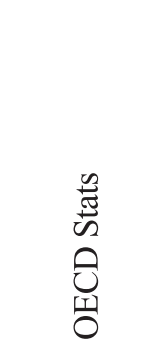 & 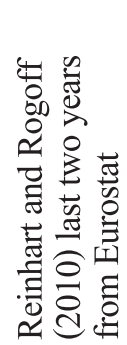 \\
\hline 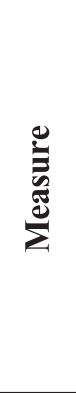 & 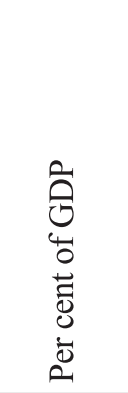 & 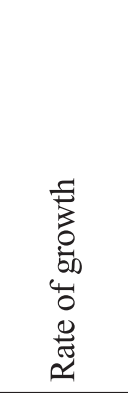 & $\begin{array}{l}n \\
0 \\
0 \\
\end{array}$ & 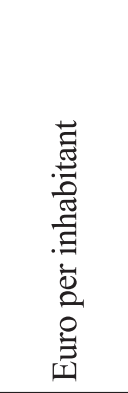 & 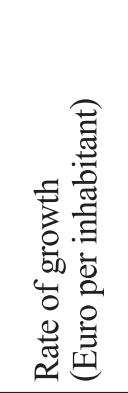 & 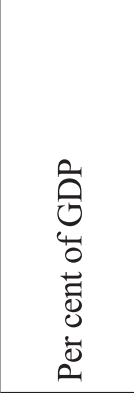 & 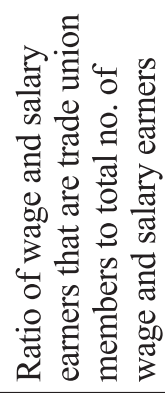 & 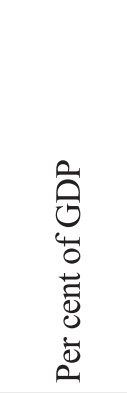 \\
\hline 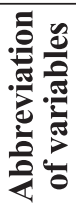 & 国 & 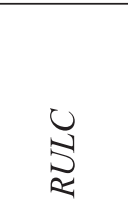 & 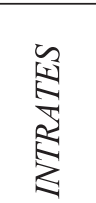 & 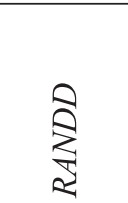 & 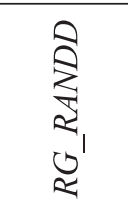 & 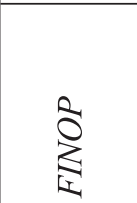 & $\frac{2}{\vdots}$ & \begin{tabular}{l}
$\widehat{\otimes}$ \\
\multirow{0}{0}{}
\end{tabular} \\
\hline 苞 & 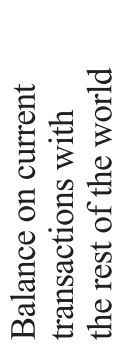 & 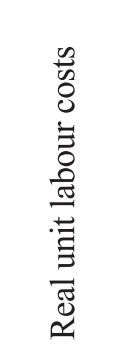 & 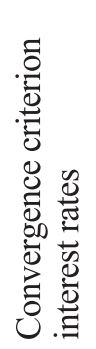 & 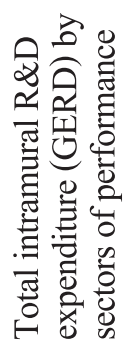 & 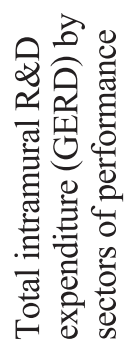 & 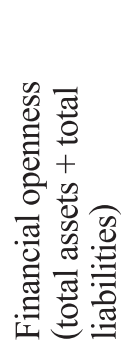 & 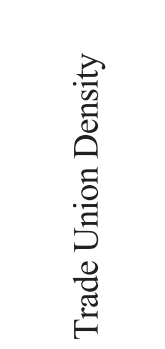 & 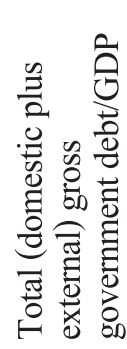 \\
\hline
\end{tabular}


兽

\begin{tabular}{|c|c|c|c|c|c|c|c|c|c|c|}
\hline है & 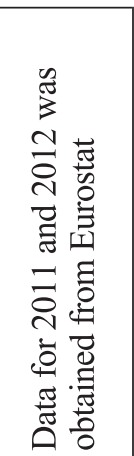 & 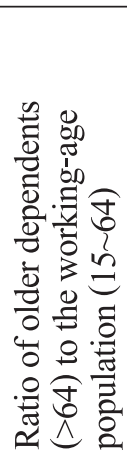 & & 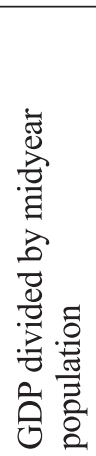 & 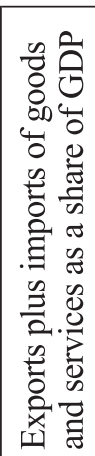 & 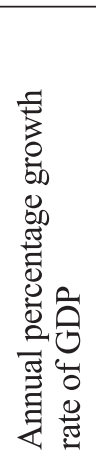 & 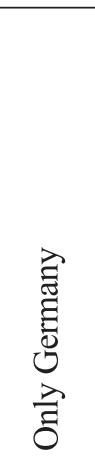 & 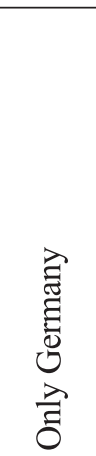 & $\begin{array}{l}\text { : } \\
\text { की } \\
\text { ते } \\
\text { ठ }\end{array}$ & $\begin{array}{l}\text {. } \\
\text { जू } \\
\text { ते } \\
\text { ते }\end{array}$ \\
\hline 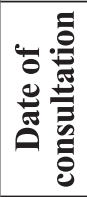 & $\underset{\substack{0 \\
\stackrel{n}{n}}}{\stackrel{\infty}{c}}$ & 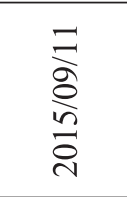 & $\begin{array}{l}\vec{\Xi} \\
\stackrel{2}{a} \\
\stackrel{2}{a}\end{array}$ & 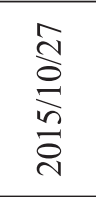 & 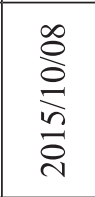 & 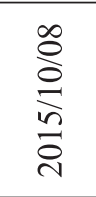 & & & & \\
\hline 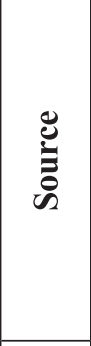 & 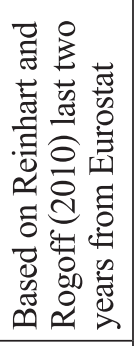 & 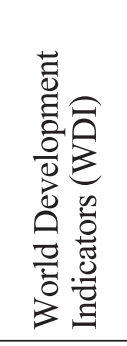 & 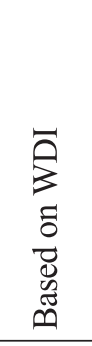 & 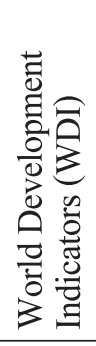 & 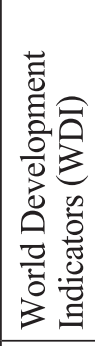 & 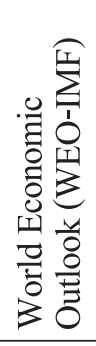 & & & & \\
\hline 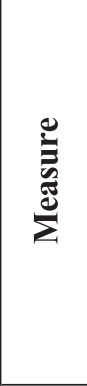 & 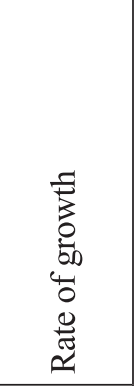 & 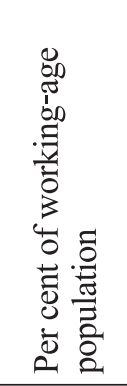 & 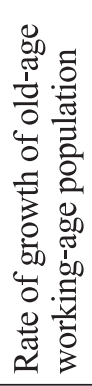 & 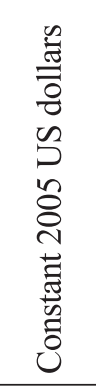 & 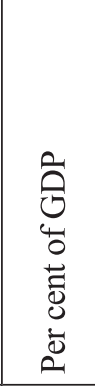 & 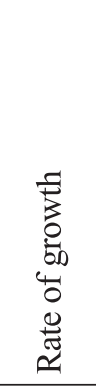 & & & & \\
\hline 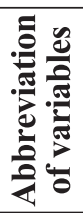 & 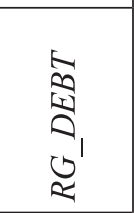 & $\begin{array}{l}\text { st } \\
\text { sy } \\
0\end{array}$ & 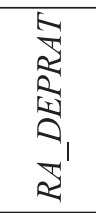 & 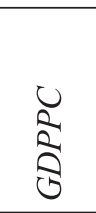 & 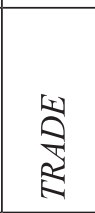 & จิ & $\begin{array}{l}0_{1} \\
\bar{a}^{\prime}\end{array}$ & $\begin{array}{l}0, \\
\tilde{a}^{\prime}\end{array}$ & $\begin{array}{l}n_{1} \\
\bar{a}^{\prime}\end{array}$ & $\begin{array}{l}\tilde{n}_{1} \\
\tilde{a}^{\prime}\end{array}$ \\
\hline 竎 & 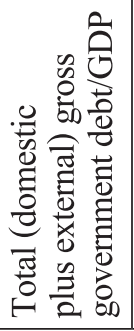 & 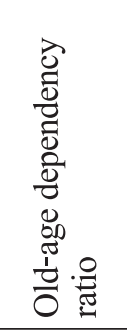 & 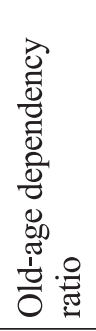 & 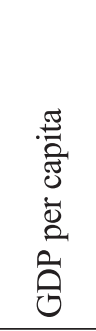 & 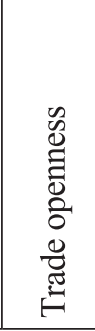 & 宅 & 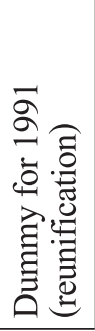 & 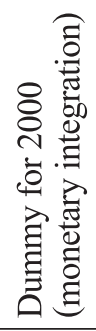 & 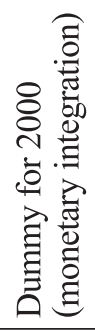 & 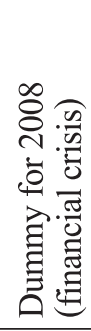 \\
\hline
\end{tabular}


During the period of our study, different events may have affected the trend of the series (e.g., German reunification, or adoption of the euro). Accordingly, as a first step, we implement breakpoint tests. Table 2 shows the results of the Bai-Perron breakpoint tests (Bai 1997, Bai and Perron 1998, and critical values from Bai and Perron 2003) for the external balance series over the period 1980 2012. In the German case, the different specifications in the breakpoint tests indicate a break in 1991, the year of German reunification. In addition, breakpoint tests show a break in the years around the introduction of the single currency. For these reasons, we create two dummy variables, where D1_G takes the value 1 in 1991 and 0 otherwise, and D2_G takes the value 1 in 2000 and 0 otherwise. For the Spanish case, breakpoint tests point to a structural break in the years around euro introduction - as in the German case - and another break related to the beginning of the global financial crisis. Therefore, we introduce two dummy variables, where D1_S takes the value 1 in 2000 and 0 otherwise, and D2_S takes the value 1 in 2008 and 0 otherwise. All these dummy variables are used as fixed regressors in the estimations.

Table 2. Structural breaks

(1980 2012)

\begin{tabular}{|c|c|c|}
\hline \multirow{2}{*}{ Model } & \multicolumn{2}{|c|}{ Bai-Perron test } \\
\hline & Constant & Constant and trend \\
\hline Germany & $1985,1991,2004$ & 1991,2004 \\
\hline Spain & 2000 & 2005 \\
\hline \multirow{2}{*}{ Model } & \multicolumn{2}{|c|}{ Global Information Criteria (Schwarz Criteria) } \\
\hline & Constant & Constant and trend \\
\hline Germany & $1985,1991,2002,2006$ & 1986, 1991, 2000, 2008 \\
\hline Spain & 1984, 1988, 2000, 2005, 2009 & 1984, 1989, 1998, 2005, 2009 \\
\hline \multirow[t]{2}{*}{ Germany } & \multicolumn{2}{|c|}{$\begin{array}{l}\text { Main breaks: } 1991 \text { (reunification) and 2000 2004 (monetary integration and } \\
\text { financial innovation). }\end{array}$} \\
\hline & \multicolumn{2}{|c|}{ Graphically, main breaks are in 1991, 1999, and 2008.} \\
\hline \multirow{2}{*}{ Spain } & \multicolumn{2}{|c|}{$\begin{array}{l}\text { Main breaks: around } 1986 \text { (entrance into EU), around } 2000 \text { (monetary integration } \\
\text { and financial innovation) and around } 2009 \text { (global financial crisis). }\end{array}$} \\
\hline & \multicolumn{2}{|c|}{$\begin{array}{l}\text { Graphically, main breaks are at the beginning of the Eurozone (1997 2000) } \\
\text { and starting the global financial crisis (2007 2008). }\end{array}$} \\
\hline
\end{tabular}

(Note) Results of Bai-Perron tests for structural breaks on the EB (balance on current transactions with the rest of the world) variables.

(Source) Own results based on Bai (1997) and Bai and Perron (1998, 2003). 
We implement the ARDL bounds testing approach as proposed by Pesaran and Shin (1999) and Pesaran, Shin, and Smith (2001). We apply this methodology to examine the long-term relationship between the external imbalances measured by EB and other relevant variables within the theoretical framework developed above. The ARDL bounds testing approach has several advantages in comparison to other popular cointegration techniques, as per Ang (2009), Narayan (2005), Pesaran, Shin, and Smith (2001), and Pesaran and Shin (1999). These are: 1) variables $I(0), I(1)$, or a combination of both can be used; 2) there is the possibility of cointegration even when independent variables are endogenous; 3) the estimates of the short-term model are consistent with their long-term parameters for small sample sizes (from 30 observations).

We follow a three-step procedure. First, we implement unit root tests to verify the order of integration of the variables. For the ARDL bounds technique, variables must be $I(0)$ or $I(1)$. Second, we select the optimal number of lags for the different variables per the Akaike Information Criterion (AIC) with a maximum of 4 lags. Finally, once the optimal number of lags has been selected, we estimate the model and test for cointegration. The first condition for the variable to be cointegrated is that the estimated F-statistic lies above the upper bound, i.e., F-stat $>I(1)$ bound. The second condition for cointegration is that the error correction term must be negative, implying that exogenous variables return to long-term equilibrium.

Based on the framework developed above, we estimate one model representing each hypothesis. In the case of the first hypothesis (catching-up in the context of economic and financial integration), we use as independent variables GDP per capita (GDPPC), the interest rate (INTRATES), and financial openness (FINOP), for Spain. First, in a panel framework, GDPPC would be expected to have a positive sign, as a more developed country tends to have a positive external balance. However, in this case, with individual time series, a less developed country tends to grow faster than a more developed country, increasing its demand for imports, and thus worsening the external balance. In contrast, in a developed country, with a lower rate of growth, EB will not deteriorate as fast as a less developed country.

Second, those countries with lower levels of development within the EMU have benefited from financial liberalisation with a decrease in interest rates. For this reason, we expect INTRATES to have a negative sign in the current account.

Finally, a variable accounting for liberalisation of the financial market is introduced. When financial liberalisation happens in relatively less developed countries, a worsening of the current account is expected due to capital flows going into that country (negative 
sign for less developed countries), whereas in the case of a more developed country, financial openness represents an opportunity for investment abroad, which will translate into capital outflows (positive sign for highly developed countries). The ARDL model for Hypothesis 1 is:

$$
\begin{aligned}
\Delta E B_{t}=\alpha_{1}^{H_{1}} & +\sum_{j=0}^{p} \beta_{j}^{H_{1}} \Delta E B_{t-j}+\sum_{j=0}^{p} \gamma_{j}^{H_{1}} \Delta \text { GDPPC }_{t-j} \\
& +\sum_{j=0}^{p} \delta_{j}^{H_{1}} \Delta I N T R A T E S_{t-j}+\sum_{j=0}^{p} \varepsilon_{j}^{H_{1}} \Delta \text { FINOP }_{t-j} \\
& +\sigma_{1}^{H_{1}} E B_{t-1}+\sigma_{2}^{H_{1}} \text { GDPPC }_{t-1}+\sigma_{3}^{H_{1}} \text { INTRATES }_{t-1}+\sigma_{4}^{H_{1}} \text { FINOP }_{t-1}+\mu_{t}^{H_{1}}
\end{aligned}
$$

where superscript $H_{1}$ identifies parameters from Hypothesis $1, p$ is the optimal lag length, and $\Delta$ indicates the first difference of the variable. The null hypothesis indicates that no long-term relationship exists $\left(H_{0}: \sigma_{1}^{H_{1}}=\sigma_{2}^{H_{1}}=\sigma_{3}^{H_{1}}=\sigma_{4}^{H_{1}}=0 ; H_{1}: \sigma_{1}^{H_{1}} \neq \sigma_{2}^{H_{1}} \neq\right.$ $\sigma_{3}^{H_{1}} \neq \sigma_{4}^{H_{1}} \neq 0$ ). If the null hypothesis of no cointegration is rejected, a short-term error correction model is estimated:

$$
\begin{aligned}
\Delta E B_{t}=\alpha_{1}^{H_{1}} & +\sum_{j=0}^{p} \beta_{j}^{H_{1}} \Delta E B_{t-j}+\sum_{j=0}^{p} \gamma_{j}^{H_{1}} \Delta G D P P C_{t-j} \\
& +\sum_{j=0}^{p} \delta_{j}^{H_{1}} \Delta \text { INTRATES }_{t-j}+\sum_{j=0}^{p} \varepsilon_{j}^{H_{1}} \Delta \text { FINOP }_{t-j} \\
& +\tau^{H_{1}} E C M_{t-1}+\mu_{t}^{H_{1}}
\end{aligned}
$$

In the case of the second hypothesis (price and non-price competitiveness), for Germany, we use as independent variables: union density (UNIONS), real unit labour costs $(R U L C)$, trade openness (TRADE), and R\&D expenditure (RANDD). For Spain, instead of $\mathrm{R} \& \mathrm{D}$ expenditure, we use the rate of growth of $\mathrm{R} \& \mathrm{D}$ expenditure $\left(R G_{-}\right.$ $R A N D D$ ), due to its order of integration in levels. UNIONS bargaining power will affect price competitiveness by trying to set a rate of wage growth higher than the rate of productivity growth (negative sign). However, the evolution of the relationship between productivity and wages in Germany after reunification gives an indication of unions' behaviour as potential wage moderators when their bargaining power decreased, per 
Schnabl and Freitag (2012). If this is true, a positive sign for the UNIONS variable can be expected. RULC is introduced as a measure of price competitiveness, widely used in the economic literature (negative sign). Moreover, within this hypothesis, the higher the value for TRADE, the greater are the business opportunities from abroad. If the country is price and non-price competitive, an increase in its trade openness will improve the external balance (positive sign). Finally, $R A N D D$ reflects specialisation and is a measure of non-price competitiveness (positive sign).

For Hypothesis 2, we estimate the long-term relationship:

$$
\begin{aligned}
\Delta E B_{t}=\alpha_{1}^{H_{2}} & +\sum_{j=0}^{p} \beta_{j}^{H_{2}} \Delta E B_{t-j}+\sum_{j=0}^{p} \gamma_{j}^{H_{2}} \Delta U N I O N S_{t-j} \\
& +\sum_{j=0}^{p} \delta_{j}^{H_{2}} \Delta R U L C_{t-j}+\sum_{j=0}^{p} \varepsilon_{j}^{H_{2}} \Delta T R A D E_{t-j} \\
& +\sum_{j=0}^{p} \theta_{j}^{H_{2}} \Delta R A N D D_{t-j}+\sigma_{1}^{H_{2}} E B_{t-1}+\sigma_{2}^{H_{2}} \text { UNIONS }_{t-1} \\
& +\sigma_{3}^{H_{2}} \text { RULC }_{t-1}+\sigma_{4}^{H_{2}} \text { TRADE }_{t-1}+\sigma_{5}^{H_{2}} \text { RANDD }_{t-1}+\mu_{t}^{H_{2}}
\end{aligned}
$$

where superscript $\mathrm{H}_{2}$ identifies parameters from Hypothesis 2, $p$ is the optimal lag length, and $\Delta$ indicates the first difference of the variable. The null hypothesis indicates that no long-term relationship exists $\left(H_{0}: \sigma_{1}^{H_{2}}=\sigma_{2}^{H_{2}}=\sigma_{3}^{H_{3}}=\sigma_{4}^{H_{2}}=\sigma_{5}^{H_{2}}=0 ; H_{1}: \sigma_{1}^{H_{2}} \neq \sigma_{2}^{H_{2}} \neq\right.$ $\sigma_{3}^{H_{2}} \neq \sigma_{4}^{H_{2}} \neq \sigma_{5}^{H_{2}} \neq 0$ ). If we reject the null hypothesis of no cointegration, we proceed to the estimation of a short-term error correction model:

$$
\begin{aligned}
\Delta C_{t}=\alpha_{1}^{H_{2}} & +\sum_{j=0}^{p} \beta_{j}^{H_{2}} \Delta C A_{t-j}+\sum_{j=0}^{p} \gamma_{j}^{H_{2}} \Delta U N I O N S_{t-j} \\
& +\sum_{j=0}^{p} \delta_{j}^{H_{2}} \Delta R U L C_{t-j}+\sum_{j=0}^{p} \varepsilon_{j}^{H_{2}} \Delta T R A D E_{t-j} \\
& +\sum_{j=0}^{p} \theta_{j}^{H_{2}} \Delta R A N D D_{t-j}+\tau^{H_{2}} E C M_{t-1}+\mu_{t}^{H_{2}}
\end{aligned}
$$

For Hypothesis 3 (the role of public finance), we use as independent variables the debt-to-GDP ratio $(D E B T)$ for Germany and the rate of growth of debt ( $\left.R G_{-} D E B T\right)$ for Spain, interest rate (INTRATES), and GDP growth $(G D P)$. We use the rate of growth of 
debt for Spain due to its order of integration in levels. The focus is on the relationship between $E B$ and $D E B T$. For this hypothesis to hold, a positive relationship should be found between debt and the external balance deterioration (negative sign). In addition, INTRATES and GDP affect the debt dynamics and long-term debt sustainability. As developed above, within this hypothesis we expect GDP to present a positive sign, and INTRATES to have a negative sign.

We estimate the long-term relationship for Hypothesis 3:

$$
\begin{aligned}
\Delta E B_{t}=\alpha_{1}^{H_{3}} & +\sum_{j=0}^{p} \beta_{j}^{H_{3}} \Delta E B_{t-j}+\sum_{j=0}^{p} \gamma_{j}^{H_{3}} \Delta D E B T_{t-j} \\
& +\sum_{j=0}^{p} \delta_{j}^{H_{3}} \Delta I N T R A T E S_{t-j}+\sum_{j=0}^{p} \varepsilon_{j}^{H_{3}} \Delta G D P_{t-j} \\
& +\sigma_{1}^{H_{3}} E B_{t-1}+\sigma_{2}^{H_{3}} D E B T_{t-1}+\sigma_{3}^{H_{3}} \text { INTRATES }_{t-1}+\sigma_{4}^{H_{3}} G D P_{t-1}+\mu_{t}^{H_{3}}
\end{aligned}
$$

As in the other cases, superscript $H_{3}$ identifies parameters from Hypothesis $3, p$ is the optimal lag length, and $\Delta$ indicates the first difference of the variable. The null hypothesis indicates that no long-term relationship exists $\left(H_{0}: \sigma_{1}^{H_{3}}=\sigma_{2}^{H_{3}}=\sigma_{3}^{H_{3}}=\sigma_{4}^{H_{3}}=\right.$ $0 ; H_{1}: \sigma_{1}^{H_{3}} \neq \sigma_{2}^{H_{3}} \neq \sigma_{3}^{H_{3}} \neq \sigma_{4}^{H_{3}} \neq 0$ ). If we reject the null hypothesis of no cointegration, we proceed to the estimation of a short-term error correction model:

$$
\begin{aligned}
\Delta E B_{t}=\alpha_{1}^{H_{3}} & +\sum_{j=0}^{p} \beta_{j}^{H_{3}} \Delta E B_{t-j}+\sum_{j=0}^{p} \gamma_{j}^{H_{3}} \Delta D E B T_{t-j} \\
& +\sum_{j=0}^{p} \delta_{j}^{H_{3}} \Delta I N T R A T E S_{t-j}+\sum_{j=0}^{p} \varepsilon_{j}^{H_{3}} \Delta G D P_{t-j} \\
& +\tau^{H_{3}} E C M_{t-1}+\mu_{t}^{H_{3}}
\end{aligned}
$$

Finally, in the case of Hypothesis 4 (the aging process), we use as independent variables the rate of growth of the old-dependency ratio $\left(R G_{-} D E P R A T\right)$, interest rates (INTRATES), and GDP growth $(G D P)$. In this case, the signs will depend on the stage of the aging process: as a society grows older, its savings will increase and therefore the external balance will be positive, to address future expenditure associated with old societies (positive sign). However, an elderly society will exhibit dissaving (negative sign). For Hypothesis 4, we estimate the long-term relationship: 


$$
\begin{aligned}
\Delta E B_{t}=\alpha_{1}^{H_{4}} & +\sum_{j=0}^{p} \beta_{j}^{H_{4}} \Delta E B_{t-j}+\sum_{j=0}^{p} \gamma_{j}^{H_{4}} \Delta R G_{-} D E P R A T_{t-j} \\
& +\sum_{j=0}^{p} \delta_{j}^{H_{4}} \Delta I N T R A T E S_{t-j}+\sum_{j=0}^{p} \varepsilon_{j}^{H_{4}} \Delta G D P_{t-j} \\
& +\sigma_{1}^{H_{4}} E B_{t-1}+\sigma_{2}^{H_{4}} R G_{-} D E P R A T_{t-1} \\
& +\sigma_{3}^{H_{4}} I_{N T R A T E S}+\sigma_{4}^{H_{4}} G D P_{t-1}+\mu_{t}^{H_{4}}
\end{aligned}
$$

As in the other cases, superscript $H_{4}$ identifies parameters from Hypothesis $4, p$ is the optimal lag length, and $\Delta$ indicates the first difference of the variable. The null hypothesis indicates that no long-term relationship exists $\left(H_{0}: \sigma_{1}^{H_{4}}=\sigma_{2}^{H_{4}}=\sigma_{3}^{H_{4}}=\sigma_{4}^{H_{4}}=\right.$ $0 ; H_{1}: \sigma_{1}^{H_{4}} \neq \sigma_{2}^{H_{4}} \neq \sigma_{3}^{H_{4}} \neq \sigma_{4}^{H_{4}} \neq 0$ ). If we reject the null hypothesis of no cointegration, we proceed to estimating a short-term error correction model:

$$
\begin{aligned}
\Delta E B_{t}=\alpha_{1}^{H_{4}} & +\sum_{j=0}^{p} \beta_{j}^{H_{4}} \Delta E B_{t-j}+\sum_{j=0}^{p} \gamma_{j}^{H_{4}} \Delta R G_{-} D E P R A T_{t-j} \\
& +\sum_{j=0}^{p} \delta_{j}^{H_{4}} \Delta I N T R A T E S_{t-j}+\sum_{j=0}^{p} \varepsilon_{j}^{H_{4}} \Delta G D P_{t-j} \\
& +\tau^{H_{4}} E C M_{t-1}+\mu_{t}^{H_{4}}
\end{aligned}
$$

\section{Results}

Table 3A and Table 3B show the results of the unit root tests for Germany and Spain, respectively. We implement the augmented Dickey-Fuller test, introduced by Dickey and Fuller (1979, 1981), the Phillips-Perron test as in Phillips and Perron (1988), and unit root tests with breaks, as in Perron (1989). We select the order of integration when two or more unit root tests agree. If there are doubts about the order of integration, we complement testing by implementing the Kwiatkowski-Phillips-Schmidt-Shin (KPSS) test (Kwiatkowski et al. 1992). 


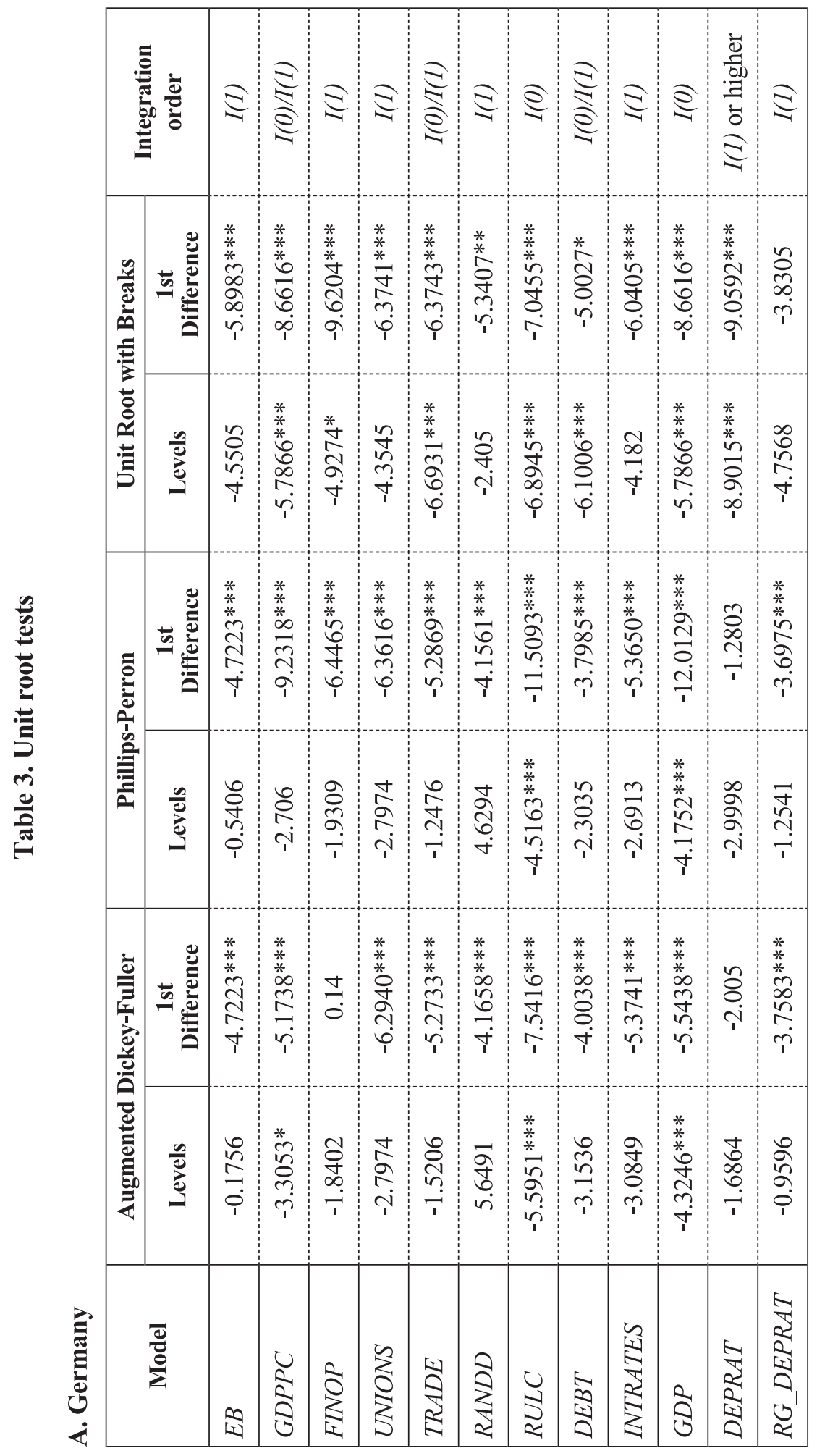




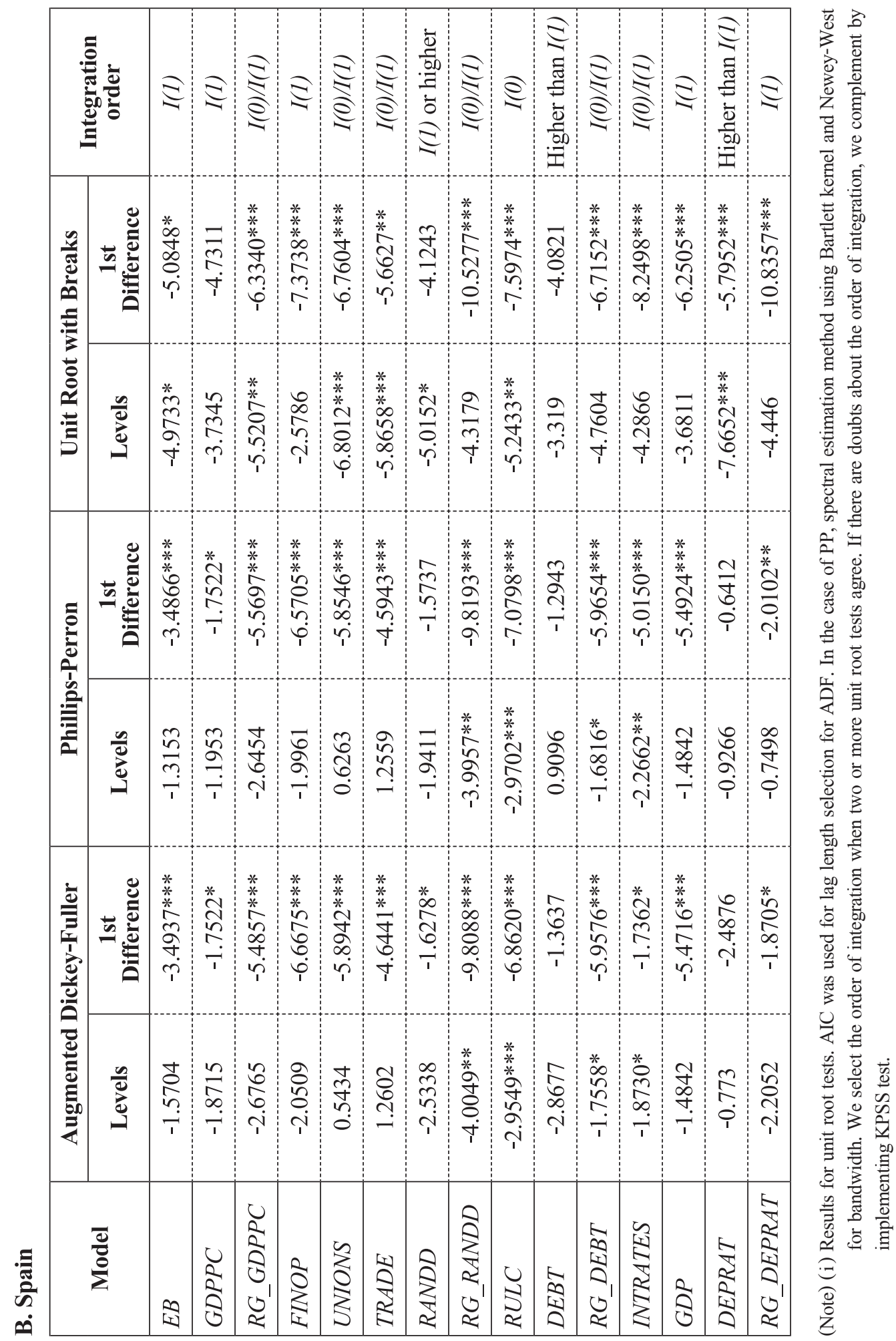


(ii) Abbreviations: $E B$ (balance on current transactions with the rest of the world); GDPPC (GDP per capita); RG_GDPPC (rate of growth of GDP per capita); FINOP (financial openness); UNIONS (trade union density); $R A N D D$ (total intramural R\&D expenditure); $R G_{-} R A N D D$ (total intramural R\&D expenditure rate of growth); RULC (real unit labour costs); $D E B T$ (total gross government debt as share of GDP); RG_DEBT (total gross government debt as share of GDP rate of growth); INTRATES (convergence criterion interest rates); GDP (GDP rate of growth); DEPRAT (old-age dependency ratio); $R G \_D E P R A T$ (old-age dependency ratio rate of growth). Implementing a KPSS test, FINOP for Germany and GDPPC, INTRATES and RG_DEPRAT for Spain have an integration order lower than 2. Therefore, we treat these variables as $I(1)$.

(iii) Significance: $* * *$ at $1 \%$; ** at $5 \%$; $*$ at $10 \%$.

In Table 4 and Table 5, we present the results of the ARDL bounds tests for Germany and Spain, respectively. For Germany, the ARDL bounds tests reject the null hypothesis of no cointegration both for Hypothesis 1 (catching-up) and Hypothesis 2 (price and non-price competitiveness). In the case of Hypothesis 2, the results indicate that there is a long-term relationship between external balance and price and non-price competitiveness. In other words, the external balance of the German economy has a longterm relationship with its economic structure. In the Spanish case, the null hypothesis of no long-term relationship is rejected both for Hypothesis 1 (catching-up) and Hypothesis 4 (aging process). 
Table 4. Testing for long-run cointegration

\begin{tabular}{|c|c|c|c|c|c|}
\hline \multicolumn{6}{|c|}{ Germany (1980 2012) } \\
\hline \multicolumn{6}{|c|}{ Dependent variable: EB; Fixed regressors: D1_G; D2_G } \\
\hline \multicolumn{3}{|c|}{$\begin{array}{c}\text { Hypothesis 1: } \\
\text { Economic and Financial Integration }\end{array}$} & \multicolumn{3}{|c|}{$\begin{array}{c}\text { Hypothesis 2: } \\
\text { Price and non-Price Competitiveness }\end{array}$} \\
\hline \multicolumn{3}{|c|}{ Variables: GDPPC, INTRATES, FINOP } & \multicolumn{3}{|c|}{ Variables: UNIONS, RULC, TRADE, RANDD } \\
\hline \multicolumn{3}{|c|}{ Selected model: ARDL $(1,3,3,4)$} & \multicolumn{3}{|c|}{ Selected model: ARDL $(4,4,4,4,4)$} \\
\hline \multicolumn{3}{|c|}{ Model section criterion: AIC } & \multicolumn{3}{|c|}{ Model section criterion: AIC } \\
\hline \multicolumn{3}{|c|}{ Number of models evaluated: 500} & \multicolumn{3}{|c|}{ Number of models evaluated: 2500} \\
\hline \multicolumn{3}{|c|}{ LM Serial Correlation: $2.1649(0.1655)$} & \multicolumn{3}{|c|}{ LM Serial Correlation: $22.9380(0.1310)$} \\
\hline \multicolumn{3}{|c|}{ Normality: $0.5387(0.7639)$} & \multicolumn{3}{|c|}{ Normality: 0.2050(0.9026) } \\
\hline \multicolumn{3}{|l|}{$F$-stat: 6.1619} & \multicolumn{3}{|c|}{$F$-stat: 57.1399} \\
\hline \multicolumn{3}{|c|}{ Critical value bound: } & \multicolumn{3}{|c|}{ Critical value bound: } \\
\hline Significance & $I(0)$ & $I(1)$ & Significance & $I(0)$ & $I(1)$ \\
\hline $10 \%$ & 2.37 & 3.2 & $10 \%$ & 2.2 & 3.09 \\
\hline $5 \%$ & 2.79 & 3.67 & $5 \%$ & 2.56 & 3.49 \\
\hline $1 \%$ & 3.65 & 4.66 & $1 \%$ & 3.29 & 4.37 \\
\hline \multicolumn{3}{|c|}{ Hypothesis 3: The Role of Public Finance } & \multicolumn{3}{|c|}{ Hypothesis 4: Aging Process } \\
\hline \multicolumn{3}{|c|}{ Variables: DEBT, INTRATES, GDP } & \multicolumn{3}{|c|}{ Variables: $R G \_D E P R A T, G D P$, INTRATES } \\
\hline \multicolumn{3}{|c|}{ Selected model: ARDL $(2,0,3,3)$} & \multicolumn{3}{|c|}{ Selected model: ARDL $(1,3,3,3)$} \\
\hline \multicolumn{3}{|c|}{ Model section criterion: AIC } & \multicolumn{3}{|c|}{ Model section criterion: AIC } \\
\hline \multicolumn{3}{|c|}{ Number of models evaluated: 500} & \multicolumn{3}{|c|}{ Number of models evaluated: 500} \\
\hline \multicolumn{3}{|c|}{ LM Serial Correlation: $0.7408(0.4945)$} & \multicolumn{3}{|c|}{ LM Serial Correlation: $1.2730(0.3152)$} \\
\hline Normality: 0.3 & $0.8495)$ & & Normality: 2.0 & $0.3524)$ & \\
\hline$F$-stat: 1.8174 & & & $F$-stat: 2.4208 & & \\
\hline Critical value $b$ & & & Critical value & & \\
\hline Significance & $I(0)$ & $I(1)$ & Significance & $I(0)$ & $I(1)$ \\
\hline $10 \%$ & 2.37 & 3.2 & $10 \%$ & 2.37 & 3.2 \\
\hline $5 \%$ & 2.79 & 3.67 & $5 \%$ & 2.79 & 3.67 \\
\hline $1 \%$ & 3.65 & 4.66 & $1 \%$ & 3.65 & 4.66 \\
\hline
\end{tabular}

(Note) (i) ARDL bounds test results for long run cointegration. The first condition for the variable to be cointegrated is that the estimated $F$-statistic lies above the upper bound.

(ii) Abbreviations: $E B$ (balance on current transactions with the rest of the world); GDPPC (GDP per capita); $R G$ GDPPC (rate of growth of GDP per capita); FINOP (financial openness); UNIONS (trade union density); $R A N D D$ (total intramural $\mathrm{R} \& \mathrm{D}$ expenditure); $R G_{-} R A N D D$ (total intramural $\mathrm{R} \& \mathrm{D}$ expenditure rate of growth); RULC (real unit labour costs); DEBT (total gross government debt as share of GDP); $R G_{-} D E B T$ (total gross government debt as share of GDP rate of growth); 
INTRATES (convergence criterion interest rates); GDP (GDP rate of growth); DEPRAT (old-age dependency ratio); $R G \_D E P R A T$ (old-age dependency ratio rate of growth); D1_G (dummy for 1991, reunification); $D 2 \_G$ (dummy for 2000, monetary integration).

\section{Table 5. Testing for long-run cointegration}

\begin{tabular}{|c|c|c|c|c|c|}
\hline \multicolumn{6}{|c|}{ Spain (1980 2012) } \\
\hline \multicolumn{6}{|c|}{ Dependent variable: EB; Fixed regressors: D1_S, D2_S } \\
\hline \multicolumn{3}{|c|}{$\begin{array}{l}\text { Hypothesis 1: } \\
\text { Economic and Financial Integration }\end{array}$} & \multicolumn{3}{|c|}{$\begin{array}{c}\text { Hypothesis 2: } \\
\text { Price and non-Price Competitiveness }\end{array}$} \\
\hline \multicolumn{3}{|c|}{ Variables: GDPPC, INTRATES, FINOP } & \multicolumn{3}{|c|}{ Variables: UNIONS, RULC, TRADE, RG_RANDD } \\
\hline \multicolumn{3}{|c|}{ Selected model: ARDL $(1,4,4,2)$} & \multicolumn{3}{|c|}{ Selected model: ARDL $(4,3,4,4,4)$} \\
\hline \multicolumn{3}{|c|}{ Model section criterion: AIC } & \multicolumn{3}{|c|}{ Model section criterion: AIC } \\
\hline \multicolumn{3}{|c|}{ Number of models evaluated: 500} & \multicolumn{3}{|c|}{ Number of models evaluated: 2500} \\
\hline \multicolumn{3}{|c|}{ LM Serial Correlation: $3.4057(0.0745)$} & \multicolumn{3}{|c|}{ LM Serial Correlation: 2.3617(0.3672) } \\
\hline \multicolumn{3}{|c|}{ Normality: 0.2172(0.8971) } & \multicolumn{3}{|c|}{ Normality: $2.3269(0.3124)$} \\
\hline \multicolumn{3}{|l|}{$F$-stat: 9.6069} & \multicolumn{3}{|l|}{$F$-stat: 2.2725} \\
\hline \multicolumn{3}{|c|}{ Critical value bound: } & \multicolumn{3}{|c|}{ Critical value bound: } \\
\hline Significance & $I(0)$ & $I(1)$ & Significance & $I(0)$ & $I(1)$ \\
\hline $10 \%$ & 2.37 & 3.2 & $10 \%$ & 2.2 & 3.09 \\
\hline $5 \%$ & 2.79 & 3.67 & $5 \%$ & 2.56 & 3.49 \\
\hline $1 \%$ & 3.65 & 4.66 & $1 \%$ & 3.29 & 4.37 \\
\hline \multicolumn{3}{|c|}{ Hypothesis 3: The Role of Public Finance } & \multicolumn{3}{|c|}{ Hypothesis 4: Aging Process } \\
\hline \multicolumn{3}{|c|}{ Variables: $R G \_D E B T$, INTRATES, GDP } & \multicolumn{3}{|c|}{ Variables: $R G \_D E P R A T, G D P$, INTRATES } \\
\hline \multicolumn{3}{|c|}{ Selected model: ARDL $(4,4,4,4)$} & \multicolumn{3}{|c|}{ Selected model: ARDL $(1,4,4,3)$} \\
\hline \multicolumn{3}{|c|}{ Model section criterion: AIC } & \multicolumn{3}{|c|}{ Model section criterion: AIC } \\
\hline \multicolumn{3}{|c|}{ Number of models evaluated: 500} & \multicolumn{3}{|c|}{ Number of models evaluated: 500} \\
\hline \multicolumn{3}{|c|}{ LM Serial Correlation: 0.9336(0.4523) } & \multicolumn{3}{|c|}{ LM Serial Correlation: 0.9313(0.4289) } \\
\hline Normality: 1.6 & $(0.4409)$ & & Normality: 0.5 & $0.7498)$ & \\
\hline$F$-stat: 3.5206 & & & $F$-stat: 10.063 & & \\
\hline Critical value & & & Critical value & & \\
\hline Significance & $I(0)$ & $I(1)$ & Significance & $I(0)$ & $I(1)$ \\
\hline $10 \%$ & 2.37 & 3.2 & $10 \%$ & 2.37 & 3.2 \\
\hline $5 \%$ & 2.79 & 3.67 & $5 \%$ & 2.79 & 3.67 \\
\hline $1 \%$ & 3.65 & 4.66 & $1 \%$ & 3.65 & 4.66 \\
\hline
\end{tabular}

(Note) (i) ARDL bounds test results for long run cointegration. The first condition for the variable to be cointegrated is that the estimated $F$-statistic lies above the upper bound. 
(ii) Abbreviations: $E B$ (balance on current transactions with the rest of the world); GDPPC (GDP per capita); $R G$ _GDPPC (rate of growth of GDP per capita); FINOP (financial openness); UNIONS (trade union density); $R A N D D$ (total intramural R\&D expenditure); $R G_{-} R A N D D$ (total intramural R\&D expenditure rate of growth); RULC (real unit labour costs); $D E B T$ (total gross government debt as share of GDP); RG_DEBT (total gross government debt as share of GDP rate of growth); INTRATES (convergence criterion interest rates); GDP (GDP rate of growth); DEPRAT (old-age dependency ratio); $R G \_D E P R A T$ (old-age dependency ratio rate of growth); $D 1 \_S$ (dummy for 2000, monetary integration); D2_S (dummy for 2008, financial crisis).

Table 6 shows the ARDL error correction coefficient (ECM) and long-term coefficients. We only report the results for those hypotheses with evidence of cointegration. ${ }^{2}$ Regarding Hypothesis 1 for Germany, the signs are as expected, with financial liberalisation resulting in capital outflows and an improvement in its current account. As Germany is a relatively more developed country, the coefficient of GDPPC is lower than for Spain. In the case of Hypothesis 2 for Germany, RULC is not significant in the long term, which reflects the short-term nature of the variable. $R A N D D$ is significant and positive, reflecting German specialisation in high addedvalue industries, which exerts positive effects on external balances. TRADE is positive: because of German non-price competitiveness advantages, an increase in trade openness improves the external balance. Finally, in the case of Germany, there is an increase in productivity growth greater than wage growth, with unions potentially playing a role as wage moderators after losing bargaining power.

${ }^{2}$ Estimation details are available upon request from the authors. 
Table 6. ARDL cointegrating and long-run coefficients

\begin{tabular}{|c|c|c|c|c|}
\hline & \multicolumn{2}{|c|}{ Germany } & \multicolumn{2}{|c|}{ Spain } \\
\hline & Hypothesis 1 & Hypothesis 2 & Hypothesis 1 & Hypothesis 4 \\
\hline$G D P P C$ & $\begin{array}{c}-0.0012 \\
(-11.012)^{* * *}\end{array}$ & & $\begin{array}{c}-0.0043 \\
(-2.772) * *\end{array}$ & \\
\hline FINOP & $\begin{array}{c}0.0398 \\
(7.433)^{* * *}\end{array}$ & & $\begin{array}{c}-0.0683 \\
(-2.161)^{*}\end{array}$ & \\
\hline UNIONS & & $\begin{array}{l}2.2671 \\
(3.79) *\end{array}$ & & \\
\hline$T R A D E$ & & $\begin{array}{c}0.5091 \\
(2.921)^{*}\end{array}$ & & \\
\hline$R A N D D$ & & $\begin{array}{c}0.0373 \\
(5.984) * *\end{array}$ & & \\
\hline$R U L C$ & & $\begin{array}{l}10.6027 \\
(1.698)\end{array}$ & & \\
\hline INTRATES & $\begin{array}{c}-1.5979 \\
(-4.298) * * *\end{array}$ & & $\begin{array}{c}-4.7273 \\
(-2.683) * *\end{array}$ & $\begin{array}{c}0.4620 \\
(2.531)^{*} *\end{array}$ \\
\hline$G D P$ & & & & $\begin{array}{c}-2.5831 \\
(-2.273)^{* *}\end{array}$ \\
\hline$R G \_D E P R A T$ & & & & $\begin{array}{l}-1.0631 \\
(-1.085)\end{array}$ \\
\hline $\operatorname{ECM}(-1)$ & $\begin{array}{c}-0.9891 \\
(-8.239) * * *\end{array}$ & $\begin{array}{c}-0.4119 \\
(-35.771) * * *\end{array}$ & $\begin{array}{c}-0.3599 \\
(-7.993) * * *\end{array}$ & $\begin{array}{c}-0.4588 \\
(-8.606) * * *\end{array}$ \\
\hline
\end{tabular}

(Note) (i) Results for ARDL cointegrating and long-run coefficients. The second condition for cointegration is that the error correction term must be negative.

(ii) Abbreviations: GDPPC (GDP per capita); FINOP (financial openness); UNIONS (trade union density); RANDD (total intramural R\&D expenditure); RULC (real unit labour costs); INTRATES (convergence criterion interest rates); GDP (GDP rate of growth); $R G$ _DEPRAT (old-age dependency ratio rate of growth); ECM (error correction term).

(iii) Significance: $* * *$ at $1 \% ; * *$ at $5 \% ; *$ at $10 \%$; $t$-statistics in parentheses.

For Spain, the catching-up hypothesis plays a key role in the evolution of the external balance. As mentioned above, in a panel data framework, we could expect GDPPC to be negative due to the differences between countries. However, in an individual time series framework, as developed here, a negative sign could be expected, as a relatively less developed country tends to grow faster than a relatively highly developed country, and this will be reflected in a more rapid worsening of its external balance through an increased demand for imports. This is the case for the Spanish economy. In addition, 
as expected, financial liberalisation worsens the external balance by increasing capital inflows into the country.

Summarising, empirical evidence supports Hypothesis 1 (catching-up process) as a key determinant factor when explaining external imbalances for both countries, Spain and Germany. In view of the higher relative returns associated with the convergence process, financial flows went from the relatively more developed countries to the less developed countries, which was reflected in the current account. The adoption of the euro - eliminating exchange rate risk - and the high expectations of future GDP growth in peripheral countries - not associated with a change in macroeconomic fundamentals per Ca'Zorzi et al. (2012) - accelerated financial flows and worsened current account balances. Overall, this result reaffirms previous research that one of the main causes of external imbalances lies in the convergence process (Belke and Dreger 2013, Blanchard and Giavazzi 2002, Campa and Gavilan 2011, Gehringer 2015, Schmitz and von Hagen 2011).

In addition, for the German case, non-price competitiveness is key to explaining the presence of external imbalances by specialisation in industries with higher added value; in other words, the results support the view that the composition of exports affects external imbalances (Wierts, van Kerkhoff, and de Haan 2014).

The production capacity of goods and services with high added value in terms of their quality, variety, and exclusiveness, in countries with the highest level of development, makes it difficult for them to find a competitor that can displace them from the market, given the constant presence of innovations in terms of products and processes. The above also implies that in the absence of an economic policy in these highly-developed countries that seek to stimulate domestic demand, and thereby contain the external surplus, it is possible to expect the persistence of external imbalances.

Finally, regarding Hypothesis 4 for Spain, the long-term coefficient of $R_{-} D E P R A T$, the key variable within this hypothesis, is not significant. In this case, there are some problems associated with the functional form of the variable, its integration order, and the number of observations. A deeper analysis of the relationship between the external balance and the aging process requires a different technique. 


\section{Final Remarks}

In this research, we have developed a theoretical and empirical framework to analyse the emergence of external imbalances in Germany and Spain over the period 1980 2012. We identify in the economic literature four hypotheses regarding the origin of external imbalances for European countries: 1) the catching-up process, 2) disparities in price and non-price competitiveness, 3 ) the role of public finance, and 4) the aging process.

Our results demonstrate that the German external balance has evolved from the economic and financial integration process, mainly through capital exports to peripheral countries, and non-price competitiveness advantages. This relates to German specialisation in high added-value industries, with unions playing a role as wage moderators after losing bargaining power.

In the case of Spain, the evolution of the external balance relates to the catching-up process in the context of European economic and financial integration. In this regard, financial liberalisation and the catching-up process incentivise capital flows into the country, boosting private investment and worsening the current account balance. The residential investment sector was one of the main recipients of capital flows.

Some important policy implications may be drawn from this analysis. Although it is not possible to lineally associate the presence of the European external imbalances with the onset of the financial crisis, they can be considered as symptoms of a structural divergence in the economic relationship between deficit and surplus countries. Therefore, a permanent solution to the problems related to external imbalances among Eurozone member countries will require addressing the determinants of such imbalances, and the implementation of asymmetric economic policies in surplus and deficits countries. For example, although there has recently been a sharp adjustment of external imbalances in deficit countries such as Spain, it is associated with a decrease in demand for imports due to the fall in income after the outbreak of the financial crisis, together with restrictive fiscal policy. Consequently, due to its structural origin, restrictive fiscal and monetary policies will only temporarily correct external imbalances, by depressing domestic demand. However, once the country returns to its potential growth rate, these imbalances will reappear. Therefore, if deficit countries such as Spain are seeking to improve their external balances permanently, they should ensure that the capital flows coming from abroad - due to expected catching-up - are allocated to tradable industries with high added value, avoiding the concentration of resources in non-tradable sectors in which 
the potential for increasing productivity is limited. In other words, such countries should focus on developing non-price competitive industries. In this case, a European industrial policy would bring potential benefits by targeting resources towards the development of these industries. Overall, there is a need to continue and deepen the debate, as discussed in Botta (2014) and Mazzucato et al. (2015), on the potential benefits of an active industrial policy in Europe.

Moreover, surplus countries will require the implementation of an expansive economic policy so as to boost domestic demand. A boost to domestic demand and a deterioration of the external balance in surplus countries could lessen the burden of deficit countries when trying to address external imbalances. In conclusion, addressing the persistent external European imbalances requires asymmetric responses from deficit and surplus countries, and the collaboration and coordination of economic policy between both groups of countries.

Received 7 January 2017, Revised 14 March 2017, Accepted 21 April 2017

\section{References}

Aizenman, Joshua, and Rajeswari Sengupta. "Global Imbalances: Is German the New China? A Sceptical View." Open Economies Review 22 (2011): 387-400.

Alessandrini, Pietro, Michele Fratianni, Andrew H. Hallet, and Andrea F. Presbitero. "External Imbalances and Fiscal Fragility in the Euro Area." Open Economies Review 25 (2014): 3-34.

Ang, James B, Financial development and economic growth in Malaysia (New York: Routledge), (2009).

Arghyrou, Michael G., and Georgios Chortareas. "Current Account Imbalances and Real Exchange Rates in the Euro Area." Review of International Economics 9 (2008): 747764.

Arghyrou, Michael G., and Alexandros Kontonikas. "The EMU sovereign-debt crisis: Fundamentals, expectations and contagion.” Journal of International Financial Markets, 
Institutions and Money 22 (2012): 658-677.

Arghyrou, Michael G., and John D. Tsoukalas. "The Greek debt crisis: Likely causes, mechanisms and outcomes." World Economy 34 (2011): 173-191.

Bai, Jushan. "Estimating multiple breaks one at a time." Econometric Theory 13(1997): 315-352.

Bai, Jushan, and Pierre Perron. "Estimating and testing linear models with multiple structural changes." Econometrica 66(1998): 47-78.

Bai, Jushan, and Pierre Perron. "Critical values for multiple structural change tests." Econometrics Journal 6(2003):72-78.

Barnes, Sebastian, Jeremy Lawson, and Artur Radziwill. "Current Account Imbalances in the Euro Area: A Comparative Perspective." OECD Economics Department Working Paper 826 (2010). http://www.oecd-ilibrary.org/economics/current-account-imbalancesin-the-euro-area_5km33svj7pxs-en. Accessed 21 March 2013.

Beirne, John, and Marcel Fratzscher. "The pricing of sovereign risk and contagion during the European sovereign debt crisis." Journal of International Money and Finance 34 (2013): 60-82.

Belke, Ansgar, and Christian Dreger. "Current Account Imbalances in the Euro Area: Does Catching up Explain the Development." Review of International Economics 21 (2013): 6-17.

Blanchard, Olivier J. "Current Account Deficits in Rich Countries.” IMF Staff Papers 54 (2007): 191-219.

Blanchard, Olivier J., and Francesco Giavazzi. "Current Account Deficits in the Euro Area: The End of the Feldstein-Horioka Puzzle?" Brookings Papers on Economic Activity 33 (2002): 147-210.

Botta, Alberto. "Structural Asymmetries at the Roots of the Eurozone Crisis: What's New for Industrial Policy in the EU?" Levy Economics Institute Working Paper 794 (2014). http://www.levyinstitute.org/publications/structural-asymmetries-at-the-root-ofthe-eurozone-crisis. Accessed 21 November 2015.

Brissimis, Sophocles N., George Hondroyiannis, Christos Papazoglou, Nicholas T. Tsaveas, and Melina A. Vasardani. "Current Account determinants and external 
sustainability in periods of structural change." Economic Change and Restructuring 45 (2012): 71-95.

Ca'Zorzi, Michele, Alexander Chudik, and Alistair Dieppe. "Thousands of models, one story. Current account imbalances in the Global economy." ECB Working Paper Series 1441 (2012). https://www.ecb.europa.eu/pub/pdf/scpwps/ecbwp1441.pdf?ed490601f7bd 04e1ec2c5c218639fa9f. Accessed 25 February 2013

Campa, Jose M., and Angel Gavilán. "Current Accounts in the Euro Area: An Intertemporal Approach.” Journal of International Money and Finance 30 (2011): 205-228.

Carlin, Wendy, and David Soskice, Macroeconomics. Imperfections, Institutions and Policies (Oxford: Oxford University Press), (2006).

Carrasco, Carlos A. "A note on European external imbalances and the euro adoption." Economics Bulletin 35 (2015): 2104-2109.

Carrasco, Carlos A., and Patricia Peinado. "On the origin of European imbalances in the context of European integration." Panoeconomicus 62 (2015): 177-191.

Chen, Ruo, Gian M. Milesi-Ferretti, and Thierry Tressel. "External imbalances in the Eurozone." Economic Policy 28 (2013): 101-142.

Christodoulopoulou, Styliani, and Olegs Tkacevs. "Measuring the effectiveness of cost and price competitiveness in external rebalancing of euro area countries: What do alternative HCIs tell us?" Empirica 43 (2016): 487-531.

De Grauwe, Paul, Economics of Monetary Union (Oxford: Oxford University Press), (2014)

Dickey, David A., and Wayne A. Fuller. "Distribution of the Estimator for Autoregressive Time Series with a Unit Root." Journal of the American Statistical Association 74 (1979): 427-431.

Dickey, David A., and Wayne A. Fuller. "Likelihood Ratio Statistics for Autoregressive Time Series with a Unit Root.” Econometrica 49 (1981): 1057-1072.

Ferreiro, Jesús, and Carmen Gómez. "Implementing a Voluntary Wage Policy: Lessons from the Irish and Spanish Wages Policies before the Crisis." Panoeconomicus 61 (2014): 107-127.

Gehringer, Agnieszka. "New evidence on the determinants of current accounts in the 
EU.” Empirica 42 (2015): 769-793.

Gibson, Heather D., Stephen G. Hall, and George S. Tavlas. "The Greek financial crisis: Growing imbalances and sovereign spreads." Journal of International Money and Finance 31 (2012): 498-516.

Hassan, A.F.M., Ruhul Salim, and Harry Bloch. "Population age structure, saving, capital flows and the real exchange rate: A survey of the literature." Journal of Economic Surveys 25 (2011): 708-736.

Hein, Eckhard, Achim Truger, and Till van Treeck. 2012. "The European Financial and Economic Crisis: Alternative Solutions from a (Post-) Keynesian Perspective.” In The Euro Crisis, edited by Philip Arestis, and Malcolm Sawyer, 35-78. Basing-Stoke: Palgrave Macmillan, 2012.

Kwiatkowski, Denis, Peter C.B. Phillips, Peter Schmidt, and Yongcheol Shin. "Testing the Null Hypothesis of Stationarity against the Alternative of a Unit Root: How Sure are we that Economic Time Series Have a Unit Root?” Journal of Econometrics 54 (1992): 159-178.

Lane, Philip, and Gian M. Milesi-Ferretti. "The external wealth of nations mark II: Revised and extended estimates of foreign assets and liabilities, 1970-2004." Journal of International Economics 73 (2007): 223-250.

Mazzucato, Mariana, Mario Cimoli, Giovanni Dosi, Joseph E. Stiglitz, Michael A. Landesmann, Mario Pianta, Rainer Walz, and Tim Page. "Which Industrial Policy Does Europe Need?" Intereconomics 50 (2015): 120-155.

Narayan, Paresh K. "The saving and investment nexus for China: evidence from cointegration tests." Applied Economics 37 (2005): 1979-1990.

Perron, Pierre. "The Great Crash, the Oil Price Shock, and the Unit Root Hypothesis." Econometrica 57 (1989): 1361-1401.

Pesaran, M.H., and Y. Shin. "An Autoregressive Distributed Lag Modelling Approach to Cointegration Analysis." In Econometrics and Economic Theory in the 20th Century: The Ragnar Frisch Centennial Symposium, edited by S. Strom, 371-413. Cambridge: Cambridge University Press, 1999.

Pesaran, M. Hashem, Yongcheol Shin, and Richard J. Smith. "Bounds testing approaches 
to the analysis of level relationships." Journal of Applied Econometrics 16 (2001): 289326.

Phillips, Peter C.B., and Pierre Perron. "Testing for a Unit Root in Time Series Regression." Biometrika 75 (1988): 335-346.

Reinhart, Carmen M., and Kenneth S. Rogoff. "From Financial Crash to Debt Crisis." NBER Working Paper 15795 (2010). http://www.nber.org/papers/w15795.Accessed 11 October 2012.

Schmitz, Birgit, and Jürgen von Hagen. "Current Account Imbalances and Financial Integration in the Euro Area." Journal of International Money and Finance 30 (2011): 1676-1695.

Schnabl, Gunther, and Stephan Freitag. "Reverse causality in global and intra-European imbalances." Review of International Economics 20 (2012): 674-690.

Wierts, Peter, Henk Van Kerkhoff, and Jakob de Haan. "Composition of Exports and Export Performance of Eurozone Countries." Journal of Common Market Studies 52 (2014): 928-941. 